\title{
PRODUCTION OF ANTIBACTERIAL AGENT FROM FUNGI ISOLATED FROM PHARMACEUTICAL SOIL SAMPLE BY FERMENTATION UNDER OPTIMIZED CONDITIONS
}

\author{
ANUPAMA BHARDWAJ*, SONIA CHAMAN, SANGEETA VERMA \\ Department of Biotechnology, Sri Guru Gobind Singh College, Sector 26, Chandigarh, India. Email: anupamabhardwaj25@yahoo.co.in
} Received: 03 March 2017, Revised and Accepted: 13 April 2017

\section{ABSTRACT}

Objective: This study aimed to isolate fungi having antibacterial activity from pharmaceutical site soil sample and production of antibacterial agents by solid and submerged state fermentation under optimized conditions. Antibacterial activity of laboratory isolated and produced antibacterial agent was compared with other commercialized antibiotics to check the efficiency of laboratory produced antibacterial agent.

Methods: For isolation and characterization of fungal isolates American Public Health Association standard was followed. Antibacterial activity was determined using disc diffusion and agar disc diffusion method.

Results: On the basis of morphological and microscopic characteristics six fungal isolates belongs to four different genus species, i.e., Aspergillus sp. (F1, F2, F3), Penicillium sp. (F4), Rhizopus sp. (F5), and Fusarium sp. (F6), and they were tested against six bacterial isolates, i.e., Streptococcus sp. (B1), Bacillus sp. (B2), Staphylococcus sp. (B3), Bacillus sp. (B4), Bacillus sp. (B5), and Enterococcus sp. (B6). Except B4 all bacterial isolates growth were inhibited by fungal isolates. Under optimized conditions maximum zone of inhibition, i.e., $78 \mathrm{~mm}$ against B1 and B5 shown by F1 and F6 at 2\% and $1 \%$ glucose concentration, respectively, at $10 \mathrm{pH}$. When comparison was made between commercialized antibiotics and lab produced antibacterial agents, it was observed lab produced antibacterial agent was more efficient in terms of zone of inhibition.

Conclusion: Lab isolated and produced antibacterial agents were more efficient than commercialized antibiotics. This study demonstrated that lab isolated antibacterial agents isolated from six fungal isolates seems to be a stable and potent antibacterial and can be used as alternative to expensive commercialized antibiotics.

Keywords: Antibacterial, Fungi, Disc diffusion, Fermentation.

(c) 2017 The Authors. Published by Innovare Academic Sciences Pvt Ltd. This is an open access article under the CC BY license (http://creativecommons. org/licenses/by/4. 0/) DOI: http://dx.doi.org/10.22159/ajpcr.2017.v10i7.18258

\section{INTRODUCTION}

Antibiotic is a medicinal substance used to treat infections caused by microbes that can cause disease to higher level of eukaryotic organisms. Antibiotic functions to break down the bacterial cells that cause certain disease because antigenic substances are present on the cell wall of bacteria. Microorganisms are the most potential source for production of natural therapeutic agents [1]. In fact, to maintain their niche and territory, bacteria produce antibiotic as secondary metabolite. There are few classes of microorganisms that can be used as sources for clinically useable antibiotics [2].

Today at global level health care is facing the problem of emergence of multi-resistant bacteria thus threat of epidemics and pandemics [3] and became a major global health problem $[4,5]$. Several factors have favored this scenario such as extensive and often inappropriate use of antibiotics, poor hygienic conditions, emigration/immigration of travelers, increased numbers of immunocompromised patients, and delay in diagnosis of infections [6]. The tremendous increase in antibiotics resistant bacterial species leads to the invention of new sources of antibiotics through microorganisms such as bacteria, fungi, and actinomycetes [7]. The antibiotics produced by microbes have been gaining importance by many researchers. Soil is considered one of the most suitable habitats or environments for microbial growth. The pace of development of genuinely new antimicrobial agent is disappointingly slow.

For the human health and nutrition fungi are well known to produce both beneficial and deleterious natural agents and continue to be explored as useful sources of natural antimicrobial agents. In comparison to plants, microorganisms are highly diverse but narrowly explored. Till date, only about $1 \%$ of bacteria and $5 \%$ of fungi have been characterized while rest remains unexplored for their contribution to the human welfare [8]. In recent years, the isolation of fungi from soil and screening of antimicrobial activity has gained more attention. Present study worked on isolation of fungi having antibacterial activity and compared antibacterial activity with commonly prescribed antibiotics so antibacterial agent from fungi having high activity against bacteria will be used as feasible and economical option to commercialized antibiotics.

Based on the above-mentioned literatures, this study is an attempt to isolate fungi from pharmaceutical site soil sample and to investigate the antimicrobial activity of certain soil microorganisms, i.e., fungi isolated from the soil sample. Crude extract of fungi was prepared and was tested for antibacterial activities against a set of test bacteria. To evaluate their antibacterial efficiency, antibacterial activity was compared w'ith commercially available antibiotics. Further, antibacterial agent from isolated fungi was produced by solid state and submerged fermentation.

\section{METHODS}

\section{Procurement of wastewater samples}

Sampling of soil sample was done from pharmaceutical site according to standard procedures from American Public Health Association (1989) [9].

Procurement of chemicals, media, reagents and instruments All the chemicals and analytical reagent grade were commercially obtained from HIMEDIA ${ }^{\circledast}$, Loba Chemie ${ }^{\circledR}$, SRL ${ }^{\circledR}$ (Sisco Research Laboratories) and Qualigens ${ }^{\circledR}$ and used as received without further modification. Double-distilled water was filtered through a Millipore 
membrane filter before being used. The instruments were purchased from Remi Equipment Ltd., Esico, M.S. Electronics India Pvt. Ltd. and Bio-age equipment and services.

\section{Isolation of bacterial isolates}

Soil sample bacteria were isolated by Koch method based on the serial dilution and spreading on nutrient agar. From the individual colonies resulted on the media, bacterial pure cultures were obtained by inoculation in test tubes with sloping medium surface at $37 \pm 1.0^{\circ} \mathrm{C}$, 48 hrs.

\section{Isolation of fungal isolates}

Dairy wastewater fungi were isolated by Koch method based on the serial dilution and spreading on potato dextrose agar. From the individual colonies resulted on the media, fungal pure cultures were obtained by inoculation in test tubes with sloping medium surface at $25 \pm 1.0^{\circ} \mathrm{C}, 72 \mathrm{hrs}$.

\section{Inoculum preparation}

Each bacterial isolate with $0.1 \mathrm{ml}$ suspension $\left(3.1 \times 10^{5} \mathrm{CFU} / \mathrm{ml}\right)$ was inoculated in $100 \mathrm{ml}$ inoculum medium. The flasks were kept on rotary shaker at $150 \mathrm{rpm}$ for $24 \mathrm{hrs}$ at $37^{\circ} \mathrm{C}$. Similarly, $0.1 \mathrm{ml}$ suspension of fungal isolate was inoculated in $100 \mathrm{ml}$ inoculum medium. The flask was kept on rotary shaker at $150 \mathrm{rpm}$ for 3 days at $25^{\circ} \mathrm{C}$.

To study the biodegradation efficiency of the microbial isolates, biomass of actively growing cells was prepared. For the same, each bacterial isolate was grown on $50 \mathrm{ml}$ nutrient broth and $50 \mathrm{ml}$ potato dextrose broth for fungi at $150 \mathrm{rpm}$ on rotary shaker at $32^{\circ} \mathrm{C} / 25^{\circ} \mathrm{C}$ for 24-72 hrs. Actively, growing bacterial culture of each isolate was centrifuged at $10,000 \mathrm{rpm}$ for 10 minutes to get wet pellet of each isolate and pellet was washed thrice with sterile distilled water. The pellet was resuspended in sterile deionized water till turbidity reaches at or above that of McFarland 0.5 standard [10].

\section{Cultivation for screening and isolation of secondary metabolites}

Each fungal isolate was inoculated into a $1000 \mathrm{ml}$ Erlenmeyer flask containing $300 \mathrm{ml}$ of PDB media. Depending on the fungal growth, cultures on liquid medium were incubated for 3-4 weeks. The fermentation was brought to an end by adding $250 \mathrm{ml}$ ethyl acetate to the culture flask and standing closed for at least $24 \mathrm{hrs}$.

\section{Extraction of fungal liquid cultures}

About $250 \mathrm{ml}$ ethylacetate were added to each Erlenmeyer flask containing $300 \mathrm{ml}$ culture medium and left overnight to stop cell growth. Crude extract of fungal isolates prepared according to Kalyanasundaram et al. [11], and crude extracts were subjected to antimicrobial assays.

\section{Screening of fungal isolates for antibacterial activity}

Antagonistic assay for fungal extract against bacteria

Antagonistic assay was done by an agar disk diffusion and disk diffusion method. Isolated fungal extract was tested for the antibacterial activity. Bacteria were spread on Mueller-Hinton agar (MHA) plates. Then, disks (dipped in crude fungal extract) were placed on media and $2 \mathrm{~mm}$ agar disk were also placed on media. Antagonistic activity was detected after an incubation of $24-48 \mathrm{hrs}$ at $30^{\circ} \mathrm{C}$. The presence of zone clearance on agar plates was used as an indicator for the antibacterial activity. The strains which showed the maximum zone of clearance was chosen for further study [11].

\section{Identification of potential fungal isolates}

For characterization of the morphology of fungal isolates, slides prepared from cultures were stained with lactophenol cotton blue reagent and examined under light microscope [11]

\section{Identification of test bacterial isolates}

\section{Characterization of unknown bacterial cultures}

The identification and characterization of unknown bacteria were done on the basis of microscopic observation (morphology and arrangement of cells, cultural growth characteristics on agar), Gram-stain and various biochemical tests as given by Bergey's (1984) manual of determinative bacteriology [12] and online ABIS software.

\section{Submerged fermentation}

Fungal isolates inoculum was introduced aseptically into each sterile flask containing the following ingredients (g/L): Glucose (20), $\mathrm{KNO}_{3}(2.0), \mathrm{K}_{2} \mathrm{HPO}_{4}(0.8), \mathrm{MgSO}_{4} 7 \mathrm{H}_{2} \mathrm{O}(0.7)$, and $\mathrm{KCl}(0.5)$. The $\mathrm{pH}$ was adjusted at 7.0 before sterilization. After 5 days of incubation at $30^{\circ} \mathrm{C}$. Filtration was carried out through cotton wool and followed by centrifugation at $5000 \mathrm{rpm}$ for 15 minutes [13].

\section{Extraction}

The culture filtrates were extracted twice with n-butanol and the pooled solvent extracts were evaporated to dryness under vacuum to yield a crude residue.

Optimization of media parameters for efficient biosynthesis of antibacterial agent

Incubation $p H$

Effect of different pH ranging from 4, 7 and 10 was examined on the biosynthesis of the selected fungal isolates.

\section{Glucose concentration}

Biosynthesis of antibacterial agent by the selected fungal isolates was studied at different glucose concentrations such as $1 \%, 2 \%$, and $3 \%$.

\section{Solid state fermentation}

The static experiments were conducted in Erlenmeyer flasks containing $10 \mathrm{~g}$ wheat bran (particle size $500 \mu \mathrm{m}-1 \mathrm{~mm}$ ) as substrate. $1 \%$ ammonium sulfate was added to the substrate as additional nutrient. After sterilization inoculated the substrate with $1 \mathrm{ml}$ inoculum and moistened with appropriate amount of autoclaved seawater so that the final moisture content was $60 \%(\mathrm{w} / \mathrm{v})$. Fermentation was carried out for 7 days at $30^{\circ} \mathrm{C}$. After incubation, the extraction and antibiotic assays were carried out.

\section{Extraction of antibiotic (crude extract)}

Extraction of antibiotic was done by the addition of $50 \mathrm{ml}$ distilled water to the fermented substrate $(10 \mathrm{~g})$. Filtration was done using cheese cloth and the filtrate was subjected to centrifugation at $10,000 \mathrm{rpm}$ for 10 minutes. The supernatant was used for antibiotic assay [14].

Compare of antibacterial activity of fungal isolates with commercialized antibacterial agents on the basis of zone of inhibition

Determination of minimum inhibitory concentration value was carried out using disk diffusion method. Antibacterial agent disk (fungal isolates) was placed onto the MHA media inoculated with test bacteria. Seven commercialized antibiotic discs, i.e., erythromycin, fluconazole, voriconazole, cefotaxime, ceftriaxone, cefixime, and nalidic acid were also placed onto the MHA media inoculated with test bacteria. The plate was incubated at $30^{\circ} \mathrm{C}$ for $24-48 \mathrm{hrs}$. The diameter of the inhibition zone formed around the disc was measured [2].

\section{Statistical analysis}

The results are presented as the means \pm standard deviation [15].

\section{RESULTS AND DISCUSSION}

Sample collection, isolation, and identification of fungi and bacteria at genus level

A systematic study about the fungal biodiversity in pharmaceutical site soil was carried out to evaluate their capacity to produce the bioactive compound. A total of six fungi were isolated from soil sample by spreading and streaking method using potato dextrose agar media for cultivation. Six bacteria were also isolated from soil sample by spreading and streaking method using nutrient agar media and used 
as test organisms on which fungi were screened for their antifungal activity. The colony morphology and microscopic characterization of each bacterial isolate and fungal isolate are illustrated in Table 1, Table 2 and Table 3. Dos Santos et al. [6] isolated 65 fungi from the leaves of Indigofera suffruticosa and screened them for their antimicrobial activity. Svahn et al. [3] isolated 61 fungal isolates from highly antibioticcontaminated river sediments and their screened fungal isolates for their antibacterial activity.

\section{Screening of fungal isolates having antibacterial property}

Antibacterial activity of crude extract by agar disc diffusion and paper disc method

The antibacterial activity at concentration of $25 \mathrm{mg} / \mathrm{ml}$ of ethyl acetate extracts of fungi was tested against six bacteria, i.e., B1, B2, B3, B4, B5, B6 had shown broad-spectrum activity which has been reported in Table 4. The crude extract of F1, F2, F3, F4, F5, F6 produced the highest zone of inhibition 76, 33, 60, 72, 69, and $77 \mathrm{~mm}$, respectively, against bacteria B2, B5 and B6, respectively. The crude extract F6 from ethylacetone solvent has shown the highest zone of inhibition of $77 \mathrm{~mm}$ against B2.
Solid state and submerged fermentation for production of antibacterial agent from fungal isolates

Solid-state fermentation

Optimization of antibacterial agent production

Optimization for maximum production of antibacterial agent was done at different incubation time, i.e., 2, 4, 6 days. The results obtained from the 6 day, solid-state fermentation is the best. This contains maximum amount of supernatant, which is responsible for the antibacterial activity.

Maximum antibacterial agent concentration as shown in Table 5 was achieved after 6 days of incubation. Least antibacterial agent concentration was observed after 2 days of incubation. Maximum antibacterial agent was produced by F4 followed by F1, F5, F3, F6, and F2.

Test for sensitivity

Six bacteria were tested for their sensitivity of fungal extract. The antibacterial potency was determined by the agar disc diffusion method. Table 6 shows diameters of inhibition zones exerted by the

Table 1: Morphological and microscopic analysis of fungal isolates

\begin{tabular}{|c|c|c|c|c|}
\hline Isolates & Colony characteristics & Zonation & Sporulation & Tentative fungi \\
\hline F1 & Velvety thick, creamish white & Radially furrowed & Moderate & Aspergillus sp. \\
\hline $\mathrm{F} 2$ & Velvety, white with typical black spores & Heavily furrowed on the reverse & Heavy & Aspergillus sp. \\
\hline F3 & Velvety, light yellow & With venation like radial furrows & Nil & Aspergillus sp. \\
\hline F4 & Powdery, olivaceous green with sterile white margin & Radially furrowed & Heavy & Penicillium sp. \\
\hline F5 & Cottony, white & Radially furrowed & Moderate & Rhizopus sp. \\
\hline F6 & Floccose, magenta pink & $\begin{array}{l}\text { With concentric zones of dark and light } \\
\text { reddish coloration }\end{array}$ & Poor & Fusarium sp. \\
\hline
\end{tabular}

Table 2: Morphological and microscopic analysis of bacterial isolates

\begin{tabular}{lll}
\hline Isolates & Colony characteristics & $\begin{array}{c}\text { Gram } \\
\text { reaction }\end{array}$ \\
\hline B1 & & Positive \\
B2 & Branching growth pattern with yellowish white appearance & Positive \\
B3 & Circular, convex, smooth, golden yellow & Positive \\
B4 & Small, round, regular, red color pigmented & Positive \\
B5 & Small, circular, regular, pale yellow color pigmentation & Positive \\
B6 & Large, irregular, greenish yellow fluorescent colonies & Negative \\
\hline
\end{tabular}

Table 3: Biochemical characterization of bacterial isolates

\begin{tabular}{lllllllll}
\hline Isolates & Catalase & Citrate & MR & VP & Indole & Nitrate & $\mathbf{H}_{2} \mathbf{S}$ & Tentative bacteria \\
\hline B1 & + & + & - & - & - & + & - & Streptococcus sp. \\
B2 & + & + & - & - & - & + & - & Bacillus sp. \\
B3 & + & - & - & + & - & + & - & Staphylococcus sp. \\
B4 & + & - & - & - & - & + & - & Bacillus sp. \\
B5 & + & - & - & + & - & + & - & Bacillus sp. \\
B6 & - & - & & & & - & Enterococcus sp. \\
\hline
\end{tabular}

+: Present; -: Absent, MR: Methyl red, VP: Voges Proskauer

Table 4: Antibacterial activity shown by fungal isolates against test bacteria

\begin{tabular}{|c|c|c|c|c|c|c|}
\hline \multirow[t]{2}{*}{ Isolates } & \multicolumn{6}{|c|}{ Zone of inhibition (mm) shown by fungal isolates against test bacteria } \\
\hline & F1 & F2 & F3 & F4 & F5 & F6 \\
\hline BI1 & $24( \pm 3)$ & $0( \pm 0)$ & $40( \pm 3.8)$ & $36( \pm 5.3)$ & $36( \pm 5)$ & $17( \pm 4.5)$ \\
\hline $\mathrm{BI} 2$ & $60( \pm 5)$ & $0( \pm 0)$ & $60( \pm 2.7)$ & $3( \pm 0.5)$ & $3( \pm 0.5)$ & $26( \pm 2.2)$ \\
\hline $\mathrm{BI} 3$ & $76( \pm 2.9)$ & $23( \pm 2.4)$ & $2( \pm 0)$ & $0( \pm 0)$ & $0( \pm 0)$ & $0( \pm 0)$ \\
\hline $\mathrm{BI} 4$ & $0( \pm 0)$ & $0( \pm 0)$ & $0( \pm 0)$ & $0( \pm 0)$ & $0( \pm 0)$ & $0( \pm 0)$ \\
\hline BI5 & $0( \pm 0)$ & $33( \pm 4.2)$ & $46( \pm 4.2)$ & $72( \pm 4.5)$ & $69( \pm 5.4)$ & $77( \pm 5.9)$ \\
\hline BI6 & $10( \pm 1.2)$ & $13( \pm 1.1)$ & $0( \pm 0)$ & $10( \pm 2.2)$ & $62( \pm 4.8)$ & $45( \pm 3.8)$ \\
\hline
\end{tabular}

*Each value is mean of three determination, *Values in parenthesis indicate standard deviation 
various extracts toward challenged bacteria. Clear zones against BI1, $\mathrm{BI} 2, \mathrm{BI} 3, \mathrm{BI} 5, \mathrm{BI} 6$ but in BI4 showed the hazy zones, i.e., not clear.

As compared to values of zone of inhibition ( $\mathrm{mm}$ ) of bacteria shown by six fungal isolates illustrated in Table 4 with the values given in Table 6, it was observed that under optimized treatment condition increment in zone of inhibition was noticed. From Table 4, it was observed that F1 maximally inhibit bacteria growth around $76 \mathrm{~mm}$ while under optimized condition $77 \mathrm{~mm}$. F2 maximally inhibit bacteria growth around $33 \mathrm{~mm}$ while under optimized condition $34 \mathrm{~mm}$. F3 maximally inhibit bacteria growth around $60 \mathrm{~mm}$ while under optimized condition $61 \mathrm{~mm}$. F4 maximally inhibit bacteria growth around $72 \mathrm{~mm}$ while under optimized condition $74 \mathrm{~mm}$. F5 maximally inhibit bacteria growth around $69 \mathrm{~mm}$ while under optimized condition $70 \mathrm{~mm}$. F6 maximally inhibit bacteria growth around $77 \mathrm{~mm}$ while under optimized condition $78 \mathrm{~mm}$.

\section{Submerged state fermentation}

Optimization for maximum production of antibacterial agent was done at different $\mathrm{pH}$ values, i.e., 4, 7 and 10 and at different glucose concentrations, i.e., $1 \%, 2 \%$ and $3 \%$. The results obtained from the $\mathrm{pH} 4$, 7,10 and glucose concentration $1 \%, 2 \%, 3 \%$ submerged fermentation is the best. This contains maximum amount of supernatant, which is responsible for the antibacterial activity.

It was clear from Table 7, six fungal isolates produced maximum antibacterial agent at variable $\mathrm{pH}$ range. Maximum antibacterial agent produced by F1 at pH 10, i.e., 0.24 while F2 at pH 4, i.e., 0.09 . Maximum antibacterial agent produced by $\mathrm{F} 3$ at $\mathrm{pH} 10$, i.e., 0.16 while $\mathrm{F} 4$ at $\mathrm{pH} 4$, i.e., 0.76. Maximum antibacterial agent produced by $\mathrm{F} 5$ at $\mathrm{pH} 4$, i.e., 0.14 while $\mathrm{F} 6$ at $\mathrm{pH}$ 10, i.e., 0.32. Least antibacterial agent concentration produced by $\mathrm{F} 1$ at $\mathrm{pH} 7$, i.e., 0.01 while $\mathrm{F} 2$ at $\mathrm{pH} 10$, i.e., 0.03 . Least antibacterial agent concentration produced by $\mathrm{F} 3$ at $\mathrm{pH}$ 4, i.e., 0.01 while $\mathrm{F} 4$ at $\mathrm{pH} 7$, i.e., 0.07 . Least antibacterial agent concentration produced by $\mathrm{F} 5$ at $\mathrm{pH} 7$, i.e., 0.07 while $\mathrm{F} 6$ at $\mathrm{pH} 4$, i.e., 0.01 . Maximum antibacterial agent was produced by F4 followed by F6, F1, F3, F5 and F2.
As observed from Table 8, six fungal isolates produced maximum antibacterial agent at variable glucose concentration. Maximum antibacterial agent produced by $\mathrm{F} 1$ at $2 \%$ glucose concentration, i.e., 0.90 while $\mathrm{F} 2$ at $1 \%$ glucose concentration, i.e., 0.15 . Maximum antibacterial agent produced by $\mathrm{F} 3$ at $1 \%$ glucose concentration, i.e., 0.38 while $\mathrm{F} 4$ at $1 \%$ glucose concentration, i.e., 0.08 . Maximum antibacterial agent produced by $\mathrm{F} 5$ at $1 \%$ glucose concentration, i.e., 0.09 while $\mathrm{F} 6$ at $1 \%$ glucose concentration, i.e., 0.44 . Least antibacterial agent concentration produced by $\mathrm{F} 1$ at $3 \%$ glucose concentration, i.e., 0.15 while $\mathrm{F} 2$ at $3 \%$ glucose concentration, i.e., 0.00 . Least antibacterial agent concentration produced by F3 at 2\% glucose concentration, i.e., 0.07 while $\mathrm{F} 4$ at $2 \%$ glucose concentration, i.e., 0.02 . Least antibacterial agent concentration produced by F5 at 3\% glucose concentration, i.e., 0.05 while F6 at $2 \%$ glucose concentration, i.e., 0.09 . Maximum antibacterial agent was produced by F1 followed by F6, F3, F2, F5 and F4.

\section{Test for sensitivity}

Six bacteria were tested for their sensitivity of fungal extract. The antibacterial potency was determined by the agar disc diffusion method. Table 9 shows diameters of inhibition zones exerted by the various extracts toward challenged bacteria. Clear zones against BI1, BI2, BI3, BI5, BI6 but BI4 in showed the hazy zones, i.e., not clear.

As compared to values of zone of inhibition (mm) of bacteria shown by six fungal isolates illustrated in Table 4 with the values given in Table 9, it was observed that under optimized treatment condition increment in zone of inhibition was noticed. From Table 4, it was observed that F1 maximally inhibit bacteria growth around $76 \mathrm{~mm}$ while under optimized condition $78 \mathrm{~mm}$. F2 maximally inhibit bacteria growth around $33 \mathrm{~mm}$ while under optimized condition $37 \mathrm{~mm}$. F3 maximally inhibit bacteria growth around $60 \mathrm{~mm}$ while under optimized condition $64 \mathrm{~mm}$. F4 maximally inhibit bacteria growth around $72 \mathrm{~mm}$ while under optimized condition $75 \mathrm{~mm}$. F5 maximally inhibit bacteria growth around $69 \mathrm{~mm}$ while under optimized condition $73 \mathrm{~mm}$. F6 maximally inhibit bacteria growth around $77 \mathrm{~mm}$ while under optimized condition $78 \mathrm{~mm}$.

Table 5: Antibacterial agent concentration at variable incubation period 2, 4 and 6 days

\begin{tabular}{|c|c|c|c|c|c|c|}
\hline \multirow{2}{*}{$\begin{array}{l}\text { Incubation period } \\
\text { (days) }\end{array}$} & \multicolumn{6}{|c|}{ Optical density at $600 \mathrm{~nm}$} \\
\hline & F1 & F2 & F3 & F4 & F5 & F6 \\
\hline 2 & 0.10 & 0 & 0.07 & 0.9 & 0 & 0 \\
\hline 4 & 0.25 & 0.04 & 0.18 & 1.18 & 0.27 & 0.08 \\
\hline 6 & 0.42 & 0.11 & 0.33 & 2.29 & 0.41 & 0.19 \\
\hline
\end{tabular}

Table 6: Antibacterial activity shown by fungal isolates against test bacteria under optimized condition

\begin{tabular}{|c|c|c|c|c|c|c|}
\hline \multirow[t]{2}{*}{ Isolates } & \multicolumn{6}{|c|}{ Zone of inhibition (mm) shown by fungal isolates against test bacteria } \\
\hline & F1 & F2 & F3 & F4 & F5 & F6 \\
\hline BI1 & $25(( \pm 5.2)$ & $0( \pm 0)$ & $42( \pm 3.2)$ & $37( \pm 3.5)$ & $39( \pm 3.9)$ & $18( \pm 2.2)$ \\
\hline $\mathrm{BI} 2$ & $62( \pm 4.5)$ & $0( \pm 0)$ & $61( \pm 5.2)$ & $7( \pm 1.5)$ & $7( \pm 1.2)$ & $27( \pm 2.8)$ \\
\hline BI3 & $77( \pm 5)$ & $25( \pm 2.5)$ & $8( \pm 0)$ & $0( \pm 0)$ & $0( \pm 0)$ & $0( \pm 0)$ \\
\hline BI4 & $0( \pm 0)$ & $0( \pm 0)$ & $0( \pm 0)$ & $0( \pm 0)$ & $0( \pm 0)$ & $0( \pm 0)$ \\
\hline BI5 & $0( \pm 0)$ & $34( \pm 4.4)$ & $48( \pm 3.5)$ & $74( \pm 5.5)$ & $70( \pm 5.8)$ & $78( \pm 5.6)$ \\
\hline BI6 & $12( \pm 2.4)$ & $14( \pm 1.4)$ & $0( \pm 0)$ & $12( \pm 4.6)$ & $63( \pm 4.9)$ & $46( \pm 3.3)$ \\
\hline
\end{tabular}

*Each value is mean of three determination, *Values in parenthesis indicate standard deviation

Table 7: Antibacterial agent concentration at variable $\mathrm{pH}$ range 4, 7 and 10

\begin{tabular}{|c|c|c|c|c|c|c|}
\hline \multirow[t]{2}{*}{$\mathbf{p H}$} & \multicolumn{6}{|c|}{ Optical density at $600 \mathrm{~nm}$} \\
\hline & F1 & F2 & F3 & F4 & F5 & F6 \\
\hline 4 & 0.08 & 0.09 & 0.01 & 0.76 & 0.14 & 0.01 \\
\hline 7 & 0.01 & 0.07 & 0.09 & 0.07 & 0.07 & 0.09 \\
\hline 10 & 0.24 & 0.03 & 0.16 & 0.11 & 0.09 & 0.32 \\
\hline
\end{tabular}


Table 8: Antibacterial agent concentration at variable glucose concentrations $1 \%, 2 \%$ and $3 \%$

\begin{tabular}{llllll}
\hline \multirow{2}{*}{$\begin{array}{l}\text { Glucose } \\
\text { concentration (\%) }\end{array}$} & \multicolumn{2}{l}{ Optical density at $\mathbf{6 0 0} \mathbf{~ n m}$} & & \\
\cline { 2 - 6 } & $\mathbf{F 1}$ & $\mathbf{F 2}$ & F3 & F4 & F5 \\
\hline 1 & 0.31 & 0.15 & 0.38 & 0.08 & 0.09 \\
2 & 0.90 & 0.10 & 0.07 & 0.02 & 0.08 \\
3 & 0.15 & 0.00 & 0.24 & 0.05 & 0.05 \\
\hline
\end{tabular}

Table 9: Antibacterial activity shown by fungal isolates against test bacteria under optimized condition

\begin{tabular}{|c|c|c|c|c|c|c|}
\hline \multirow[t]{2}{*}{ Isolates } & \multicolumn{6}{|c|}{ Zone of inhibition ( $\mathrm{mm}$ ) shown by fungal isolates against test bacteria } \\
\hline & F1 & F2 & F3 & F4 & F5 & F6 \\
\hline BI1 & $27( \pm 3.2)$ & $0( \pm 0)$ & $45( \pm 5.2)$ & $39( \pm 3.2)$ & $42( \pm 2.2)$ & $20( \pm 2.2)$ \\
\hline $\mathrm{BI} 2$ & $65( \pm 6.4)$ & $0( \pm 0)$ & $64( \pm 6.7)$ & $10( \pm 1.2)$ & $9( \pm 0.8)$ & $30( \pm 3.5)$ \\
\hline $\mathrm{BI} 3$ & $78( \pm 6.2)$ & $27( \pm 3.2)$ & $12( \pm 2.2)$ & $0( \pm 0)$ & $0( \pm 0)$ & $0( \pm 0)$ \\
\hline BI4 & $0( \pm 0)$ & $0( \pm 0)$ & $0( \pm 0)$ & $0( \pm 0)$ & $0( \pm 0)$ & $0( \pm 0)$ \\
\hline BI5 & $0( \pm 0)$ & $37( \pm 2.2)$ & $51( \pm 3.2)$ & $75( \pm 4.2)$ & $73( \pm 6.8)$ & $78( \pm 6.5)$ \\
\hline BI6 & $15( \pm 1.2)$ & $16( \pm 1.2)$ & $0( \pm 0)$ & $14( \pm 1.2)$ & $65( \pm 4.2)$ & $49( \pm 4.2)$ \\
\hline
\end{tabular}

*Each value is mean of three determination, *Values in parenthesis indicate standard deviation

Table 10: Antibacterial activity shown by commercialized antibiotics against test bacteria

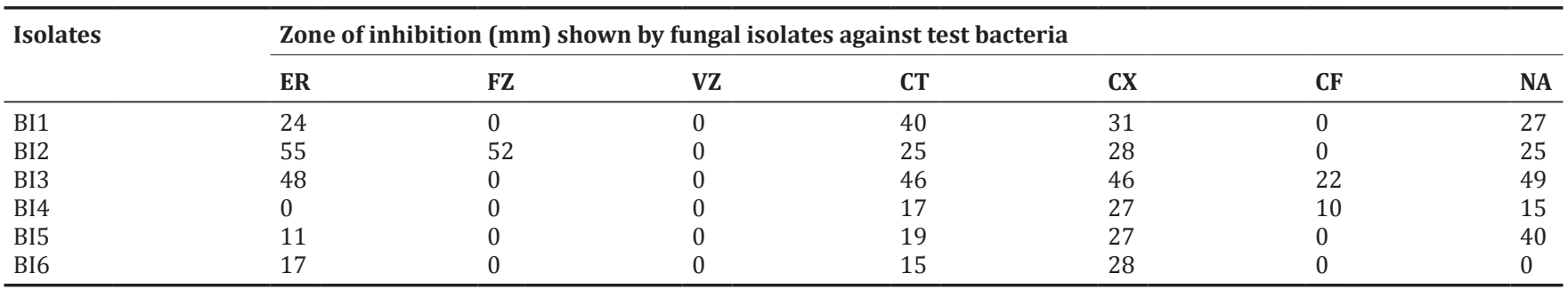

ER: Erythromycin, FZ: Fluconazole, VZ: Voriconazole, CT: Cefotaxime, CX: Ceftriaxone, CF: Cefixime, NA: Nalidic acid

Bisht et al. [16] isolated five fungal endophytes from living symptomless needle of Cupressus torulosa D. Don and characterized as such as Aspergillus sp., Fusarium sp., Cladosporium sp., Curvularia sp., and Diaporthe sp. in which, only Cladosporium sp. (PCTS23) and Curvularia sp., two (WCTS21) endophytic fungal isolates were able to show strong antagonism activity against fungal pathogen. The WCTS21 crude extract produced the highest zone of inhibition $12 \mathrm{~mm}$ for Staphylococcus aureus, whereas crude extract of PCTS23 has shown the highest zone of inhibition of $10 \mathrm{~mm}$ against $S$. aureus.

Similarly, Sandhu et al. [17] isolated and screened ten fungal isolates, viz., Aspergillus fumigates, Aspergillus japonicas, Aspergillus niger, Fusarium semitectum, Curvularia pallescens, Phoma hedericola, Alternaria tenuissima, Fusarium solani, Drechslera australien, and Aspergillus repens from medicinal plant Ricinus communis for their antibacterial activity against six human pathogenic bacterial strains Bacillus subtilis, Enterococcus sp., Klebsiella pneumoniae, Escherichia coli, Salmonella typhimurium, and S. aureus.

Desale and Bodhankar [18] isolated seventeen fungi, i.e., Colletotrichum gloeosporioides Penz, Phomopsis archeri B. sutton, Aspergillus flavus gr., Nigrospora sphaerica (Sacc.) Mason, Nonsporulating dematiaceous form, Colletotrichum gloeosporioides Penz., Alternaria raphani JW Groves, Penicillium sp., Mucor hiemalis Wehmer, Monodictys paradoxa (Corda) Hughes, Nigrospora state of Khuskia oryzae H.J. Hudson from different parts of Vitex negundo L. Antibacterial activity of fungal isolates were screened against six bacteria, viz., E. coli (NCIM No. 2345), S. typhimurium (NCIM No. 2501), Bacillus cereus (NCIM No. 2155), S. aureus (NCIM No. 2079), K. pneumoniae (NCIM No. 2706), and B. subtilis (NCIM No. 2063). The crude extract of seventeen fungal isolates with hexane, ethyl acetate and methanol were screened for their antimicrobial potential. The extract of P. archeri B. sutton in ethyl acetate showed significant antimicrobial activity against $E$. coli, S. typhimurium, B. cereus, B. subtilis, K. pneumoniae, and S. aureus. The antimicrobial activity was highest against $E$. coli $(24 \mathrm{~mm})$, followed by S. typhimurium $(22 \mathrm{~mm})$ and $B$. cereus $(16 \mathrm{~mm})$. The hexane and methanol extracts showed moderate activity against all the pathogenic organisms.

Comparative analysis of antibacterial activity of fungal isolates and commercialized antibiotics

In this study, seven commercialized antibiotics, i.e., erythromycin (ER), fluconazole (FZ), voriconazole (VZ), cefotaxime (CT), ceftriaxone (CX), cefixime (CF), and nalidic acid (NA) were used against six test bacteria and zone of inhibition was observed after 24, 48 and 72 hrs of incubation period. Zone of inhibition was shown in Table 10.

When comparison was made between antibacterial agent produced from lab isolated fungal strains and commercialized antibiotics, it was observed except bacterial isolate BI1 all bacterial strains were inhibited by all fungal isolate's antibacterial agent more efficiently as compared to commercialized antibiotics. BI1 showed maximum zone of inhibition against antibiotic cefotaxime, i.e., $40 \mathrm{~mm}$ while against fungal isolate antibacterial agent, i.e., $45 \mathrm{~mm}$. BI2 showed maximum zone of inhibition against antibiotic erythromycin, i.e., $55 \mathrm{~mm}$ while against fungal isolate antibacterial agent, i.e., $65 \mathrm{~mm}$. BI3 showed maximum zone of inhibition against antibiotic erythromycin, i.e., $48 \mathrm{~mm}$ while against fungal isolate antibacterial agent, i.e., $78 \mathrm{~mm}$. BI4 showed maximum zone of inhibition against antibiotic ceftriaxone, i.e., $27 \mathrm{~mm}$. BI5 showed maximum zone of inhibition against antibiotic nalidic acid, i.e., $40 \mathrm{~mm}$ while against fungal isolate antibacterial agent, i.e., $78 \mathrm{~mm}$. BI6 showed maximum zone of inhibition against antibiotic ceftriaxone, i.e., $28 \mathrm{~mm}$ while against fungal isolate antibacterial agent, i.e., $65 \mathrm{~mm}$.

\section{CONCLUSION}

This study raises the possibility of exploring fungal species having antibacterial activity and used them as alternative to commercialized antibiotics. Furthermore, our observations indicate that fungi from 
pharmaceutical soil sample have pharmaceutical potential as they produce antibacterial compounds and that the medicinal properties of these fungi may be a consequence of the capacity to produce biologically active secondary metabolites. Further studies are now needed to identify the active compounds produced to discover new drugs with antibacterial activity.

\section{ACKNOWLEDGMENT}

The authors express gratitude to Principal, Head Department of Biotechnology, SGGS College and Panjab University, for their valuable support during the entire study.

\section{REFERENCES}

1. Pannapa P, Pattra S. Antimicrobial and enzyme activity produced by Bacillus Spp. Isolated from soil. Int J Pharm Pharm Sci 2017;9(3):205-10

2. Lihan S, Choon YK, Hua NK, Wasli ME. Screening for antimicrobial activity of fungi in soil samples collected from Kubah National Park. Int J Sci Technol Res 2014;3(2):1-16.

3. Svahn KS, Göransson U, El-Seedi H, Bohlin L, Larsson DJ, Olsen B, et al. Antimicrobial activity of filamentous fungi isolated from highly antibiotic-contaminated river sediment. Infect Ecol Epidemiol 2012;2:1-6.

4. Girish K. Antimicrobial activities of Lantana camara Linn. Asian J Pharm Clin Res 2017;10(3):57-67.

5. Kavitha R, Dhamodharan N, Dhivya C. Screening, isolation, and antibacterial activity of antibiotic producing bacteria obtained from saprophytic soil samples. Asian J Pharm Clin Res 2017;10(3):92-6.

6. Dos Santos IP, da Silva LC, da Silva MV, de Araújo JM, Cavalcanti Mda S, Lima VL. Antibacterial activity of endophytic fungi from leaves of Indigofera suffruticosa Miller (Fabaceae). Front Microbiol 2015;6:350.

7. Sheikh HM. Antimicrobial activity of certain bacteria and fungi isolated from soil mixed with human saliva against pathogenic microbes causing dermatological diseases. Saudi J Biol Sci 2010;17(4):331-9.
8. Chioma N, Njoku EN, Pharamat T. antimicrobial activity of secondary metabolites of fungi isolated from leaves of bush mango. J Next Gener Seq Appl 2016;3(3):1-6.

9. Sonune NA, Garode AM. Bioremediation potential of bacterial isolates for municipal wastewater treatment. Curr World Environ 2015;10(2):619-25.

10. Porwal HJ, Mane AV, Velhal SG. Biodegradation of dairy effluent by using microbial isolates obtained from activated sludge. Water Resour Ind 2015;9C:1-15.

11. Kalyanasundaram I, Nagamuthu J, Muthukumaraswamy S. Antimicrobial activity of endophytic fungi isolated and identified from salt marsh plant in Vellar Estuary. J Microbiol Antimicrob 2015;7(2):1320.

12. Bhattacharya C, Harsha P, Gupta S, Royd SO. Isolation and characterization of bacterial isolates from agricultural soil at durg district. Indian J Sci Res 2014;4(1):221-6.

13. Atta HM. Biochemical studies on antibiotic production from Streptomyces sp: Taxonomy, fermentation, isolation and biological properties. J Saudi Chem Soc 2015;19(1):12-22.

14. Smitha SL, Philip R. Antibiotic production by a marine fungus Penicillium citrinum S36 through solid state fermentation: Optimization by response surface methodology. Int $\mathrm{J}$ Res Biomed Biotechnol 2014;4(1):6-13.

15. Rigoberto VG, Rodolfo AV, Vera LP. Chemical compounds and biological activity of an extract from Bougainvillea $\mathrm{x}$ buttiana (var. Rose) Holttum and Standl. Int J Pharm Pharm Sci 2017; 9(3): 42-6.

16. Bisht RI, Sharma D, Agrawal PK. Antagonistic and antibacterial activity of endophytic fungi isolated from needle of Cupressus torulosa D. Don. Asian J Pharm Clin Res 2016;9(3):282-8.

17. Sandhu SS, Kumar S, Aharwal RP. Isolation and Identification of endophytic fungi from Ricinus communis Linn. And their antibacterial activity. Int J Res Pharm Chem 2014;4(3):611-8.

18. Desale MG, Bodhankar MG. Antimicrobial activity of endophytic fungi isolated from Vitex negundo Linn. Int J Curr Microbiol Appl Sci 2013;2(12):389-95.

19. Rigoberto VG, Rodolfo AV, Vera LP. Chemical compounds and biological activity of an extract from Bougainvillea $x$ buttiana (var. Rose) Holttum and Standl. Int J Pharm Pharm Sci 2017;9(3):42-6. 